\title{
Development of Intraspecific Hybridization of Pleurotus flabellatus for Better Yield and Nutrition
}

\author{
Deewakar Baral $^{1 *}$, Ayon Roy ${ }^{3}$, Sukram Thapa ${ }^{1}$ and Karma Chewang Bhutia ${ }^{2}$ \\ ${ }^{1}$ Department of Plant Pathology, ${ }^{2}$ Department of Spices and Plantation Crops, Bidhan Chandra \\ Krishi Viswavidyalaya, Mohanpur, Nadia, West Bengal, India \\ ${ }^{3}$ Department of Plant Pathology, Uttar Banga Krishi Viswavidyalaya, Pundibari, \\ Cooch Behar, West Bengal, India \\ *Corresponding author
}

\begin{tabular}{|c|c|}
\hline \multicolumn{2}{|r|}{ A B S T R A C T } \\
\hline Keywords & \multirow{4}{*}{ 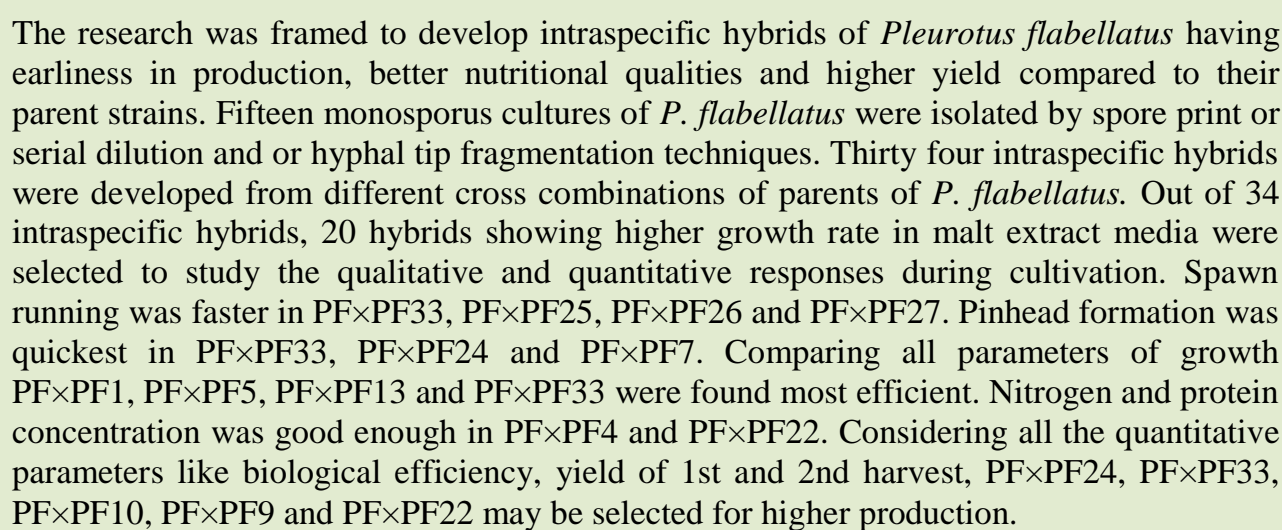 } \\
\hline $\begin{array}{l}P l \\
\text { M } \\
\text { In } \\
\text { hy }\end{array}$ & \\
\hline Arti & \\
\hline & \\
\hline
\end{tabular}

\section{Introduction}

Pleurotus which are white rot fungi of phylum basidiomycota having high saprophyte colonizing ability, can grow on any agricultural waste and show great diversity to the varying agro-climatic condition. This ability of utilizing agricultural waste into valuable product gives more importance than any other cultivated mushroom. In India, Bano and Srivastava (1962) first standardized the cultivation of Pleurotus flabellatus and first domesticated species of Pleurotus as $P$. ostreatus. Later, $P$. sajor-caju come in highlight for cultivation in
1974 when Jandaik and Kapoor first reported its cultivation on banana pseudo stem chopped with paddy straw.

Dikaryotization of selective strains is a very important tool in strain improvement for bringing genetic recombination and developing somatic hybrids which has been used by several workers to develop new strains of Pleurotus with the findings of fast colonizing ability which lead to early flushing of the fruit body with good shape, size, low mortality rate of the bud, good color of the 
pelius and the high protein content (Bahukhandi and Shrma, 2002; Jaswal et al., 2013). In this studies intraspecific hybridization of $P$. flabellatus were done through selective dikaryotization with an aim to assemble the best combination of genes into one individual hybrid with higher productivity along with better nutritional quality differing to their parents.

\section{Materials and Methods}

\section{Isolation of monosporus culture}

Following 2 different methods were followed for producing monosporus culture. Spore print method: Petersen and Ridly (1996) method was followed for the single spore isolation of both PF and PSCC (Plate 1).

Serial dilution method: Bahukandi and Sharma (2002) described the method and the same was followed with little modification for the isolation of single spore.

\section{Intraspecific hybridization: (Dual plate techniques)}

Mycelial disc of three millimeter diameter from periphery of seven days old of different monosporus cultures were placed in the two opposite sides of the Petriplates containing malt extract agar media and were incubated for 3-4 days at $25 \pm 10 \mathrm{C}$ (Plate 3).

Small inoculums was taken by chopping from the meeting points of two different isolates (Plate 4), dikaryotization was further confirmed by the formation of hyphal bridge or by the presence clamp connection (Plate 5)

\section{Parentage and intraspecific hybrids of $\boldsymbol{P}$. flabellatus}

Out of 34 intraspecific hybrids, 20 hybrids showing higher growth rate in malt extract media were selected to study the qualitative and quantitative responses during cultivation (Table 1).

\section{Cultivation of $\boldsymbol{P}$. flabellatus hybrids}

Jodon and Royse (1979) given method were followed for making of spawn of hybrids culture.

\section{Preparation of mushroom cylinder}

$3 \mathrm{~kg}$ sterilized paddy straw was filled from the opening side of polypropylene bag for about 3inch-4inch and the layer of spawn of individual strain was spread by hand and again same process of alternate layer filling of straw and spawn was practiced for 4-5 times. For each complete cylinder $200 \mathrm{gm}$ of spawn was added. Small hole was made over the polypropylene bag for aeration and cotton was plugged in the holes to protect from contamination by pathogens invasion by the insects.

\section{Quantitative estimation of Hybrid mushroom:}

Five hundred gram freshly harvested fruit body mostly from the first flush were taken as a sample for calculating the amount of dry matter. Freshly harvested mushroom was kept in a hot air oven for drying at $60^{\circ} \mathrm{C}$ for 3 days and the individual dried sample were weighed for the calculation of dry weight of mushroom. Ashraf et al., (2013) formula was followed for the calculation of moisture percent of individual sample of mushroom.

$\frac{\text { initial weight of sample-dried weight of sample }}{\text { weight of sample }} \times 100$

Most of the worker calculated biological efficiency as fresh weight of mushroom in relation to the dry weight of substrate but 
Oliveira et al., (2014) suggested that the biological efficiency will be more accurate if we compare dry weight of yield to the dry weight of substrate, so biological efficiency percent was calculated by using the formula:

\section{$\frac{\text { dry weight of mushroom }}{\text { dry weight of substrate }} \times 100$}

\section{Qualitative estimation of hybrid mushroom}

Total protein contain in dry matter of mushroom was estimated following Lowry's method (1951), Nitrogen in culture broth was determined by KEL PLUS nitrogen estimation system (Jackson, 1973).

\section{Results and Discussion}

Spawn running, pinhead formation $1^{\text {st }}$ and $2^{\text {nd }}$ flush

The earliness to reach different stages such as completion of spawn run in substrate, pinhead formation, production of $1^{\text {st }}$ and $2^{\text {nd }}$ harvestable fruit bodies within the intraspecific hybrids were calculated. The results revealed that successful spawn run in the substrate took minimum duration in $\mathrm{PF} \times \mathrm{PF} 33, \mathrm{PF} \times \mathrm{PF} 25, \mathrm{PF} \times \mathrm{PF} 26, \mathrm{PF} \times \mathrm{PF} 5$ and $\mathrm{PF} \times \mathrm{PF} 27$ (16-17 days from spawn inoculation). No spawn run was observed in $\mathrm{PF} \times \mathrm{PF} 19$ and $\mathrm{PF} \times \mathrm{PF} 20$ when they were inoculated in the rice straw. It indicated the complete abortiveness of these strains and hence excluded from selection.

Likewise, PF $\times$ PF27 although, showed earliness of spawn run, but no pinhead formation was recorded which indicated the abortiveness of the strains at this stage. Pinhead formation was found earlier in $\mathrm{PF} \times \mathrm{PF} 33, \mathrm{PF} \times \mathrm{PF} 24, \mathrm{PF} \times \mathrm{PF} 7$ (2-3 days after completion of spawn run, Table 2, Plate 7). First flush of fruits bodies was earliest in $\mathrm{PF} \times \mathrm{PF} 2, \quad \mathrm{PF} \times \mathrm{PF} 4, \quad \mathrm{PF} \times \mathrm{PF} 7, \quad \mathrm{PF} \times \mathrm{PF}$, $\mathrm{PF} \times \mathrm{PF} 11, \mathrm{PF} \times \mathrm{PF} 12, \mathrm{PF} \times \mathrm{PF} 17$ (2 days from the pinhead formation, Table 2, Plate 8) which was equal to its parent. Variation in earliness of $2^{\text {nd }}$ flush within the hybrids was found and was ranged between 7-14 days after $1^{\text {st }}$ flush.

It is evident from the results of cultivation of intraspecific hybrids of Pleurotus sp. that spawn running took 2-3 weeks after inoculation in suitable substrate which was in agreement with Tan (1981). Ahmad (1986) stated that $P$. ostreatus completed spawn running in 17-20 days on different substrates and time for pinheads formation was noted as 23-27 days. Quimio (1978) who reported that fruiting bodies 3-4 weeks after inoculation of spawn. Saha et al., (2004) reported that the earliest spawn running of 16-17 days was found in wheat straw and wheat straw supplemented with the leaves.
Plate 1
Plate 2
Plate 3

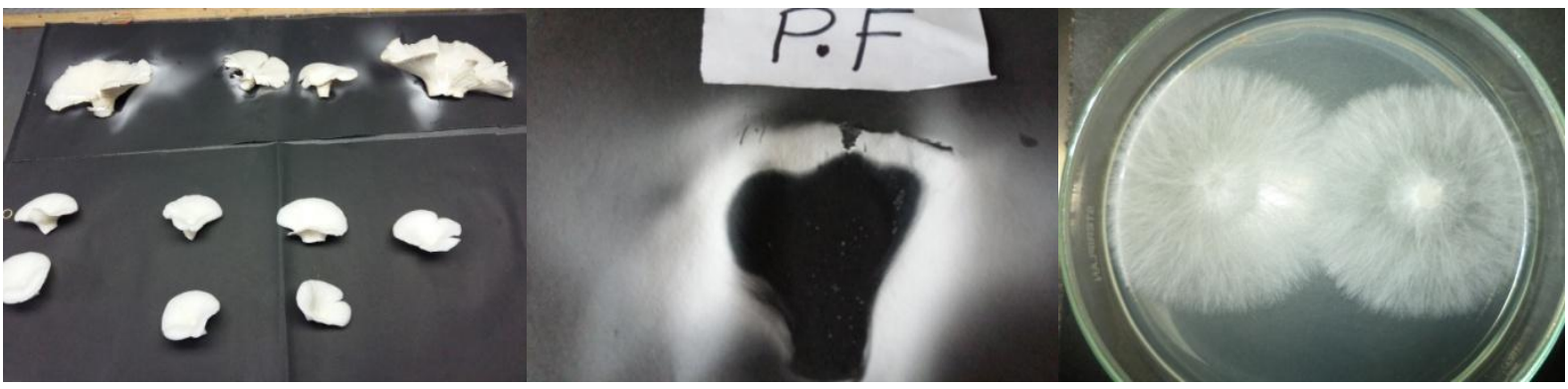




\section{Plate 4}

Plate 5

Plate 6

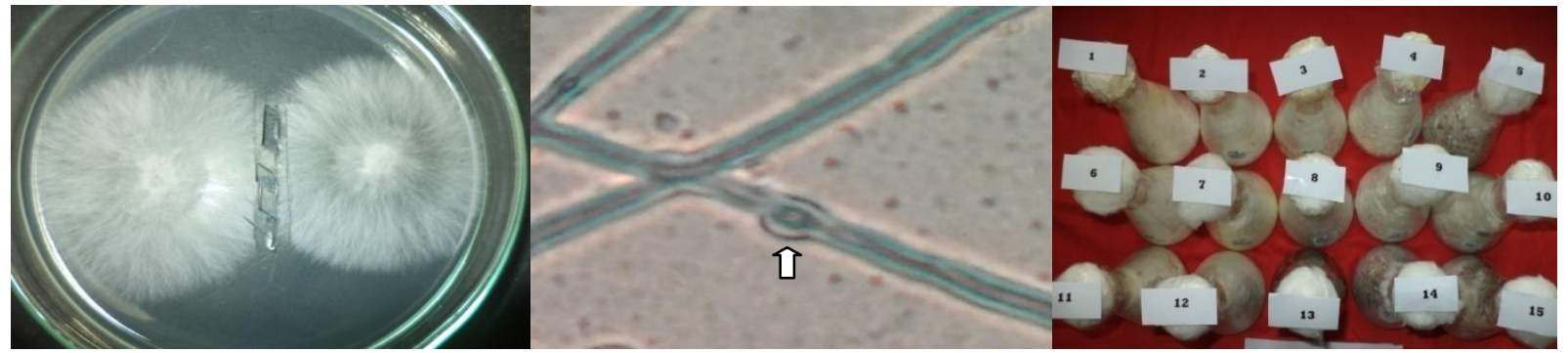

Fig 1 \& Fig 2: isolation of single spore through spore print, Fig 3: Somatic hybidization in Pleurotus, Fig 4: Isolation of dikaryotic mycellium from meeting point, Fig 5: Microscopy for presence of clamp connection to ascertain hybridization, Fig 6: Production of spawn in conical flask.

Plate 7

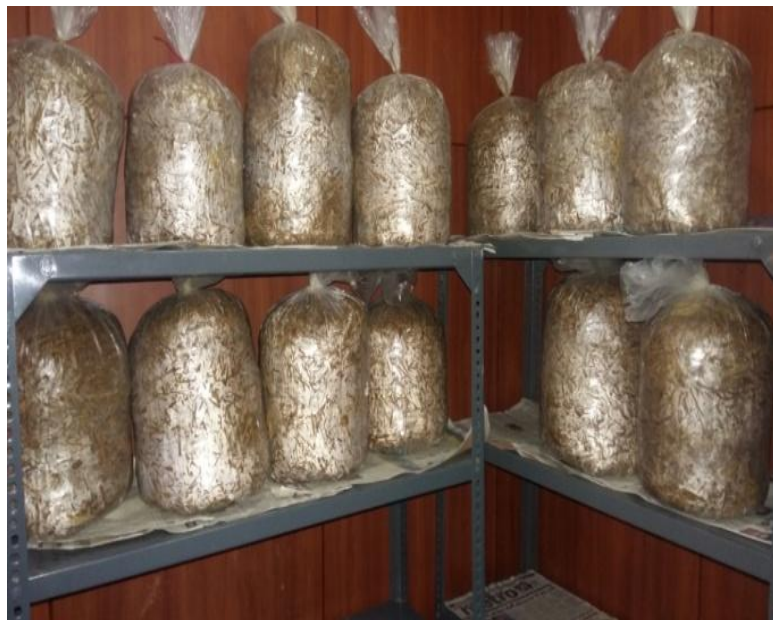

Plate 9
Plate 8

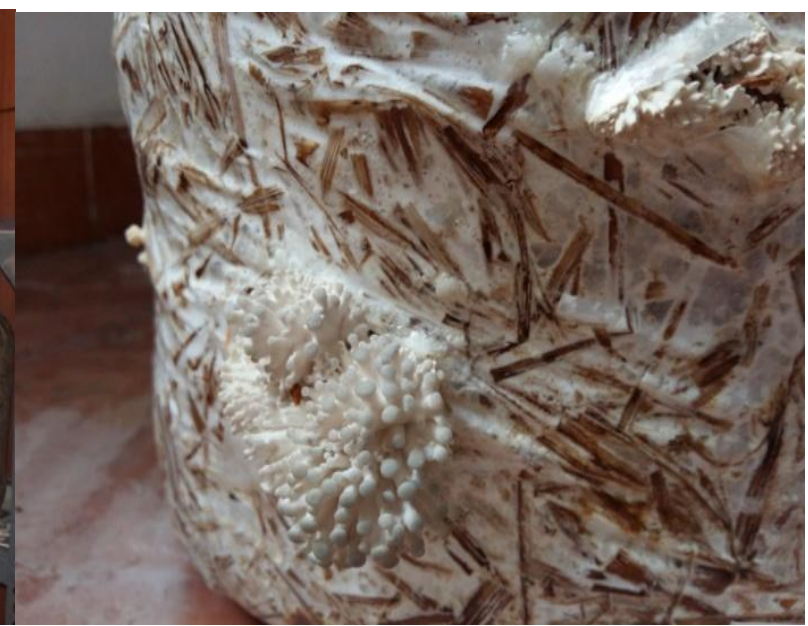

Plate 10

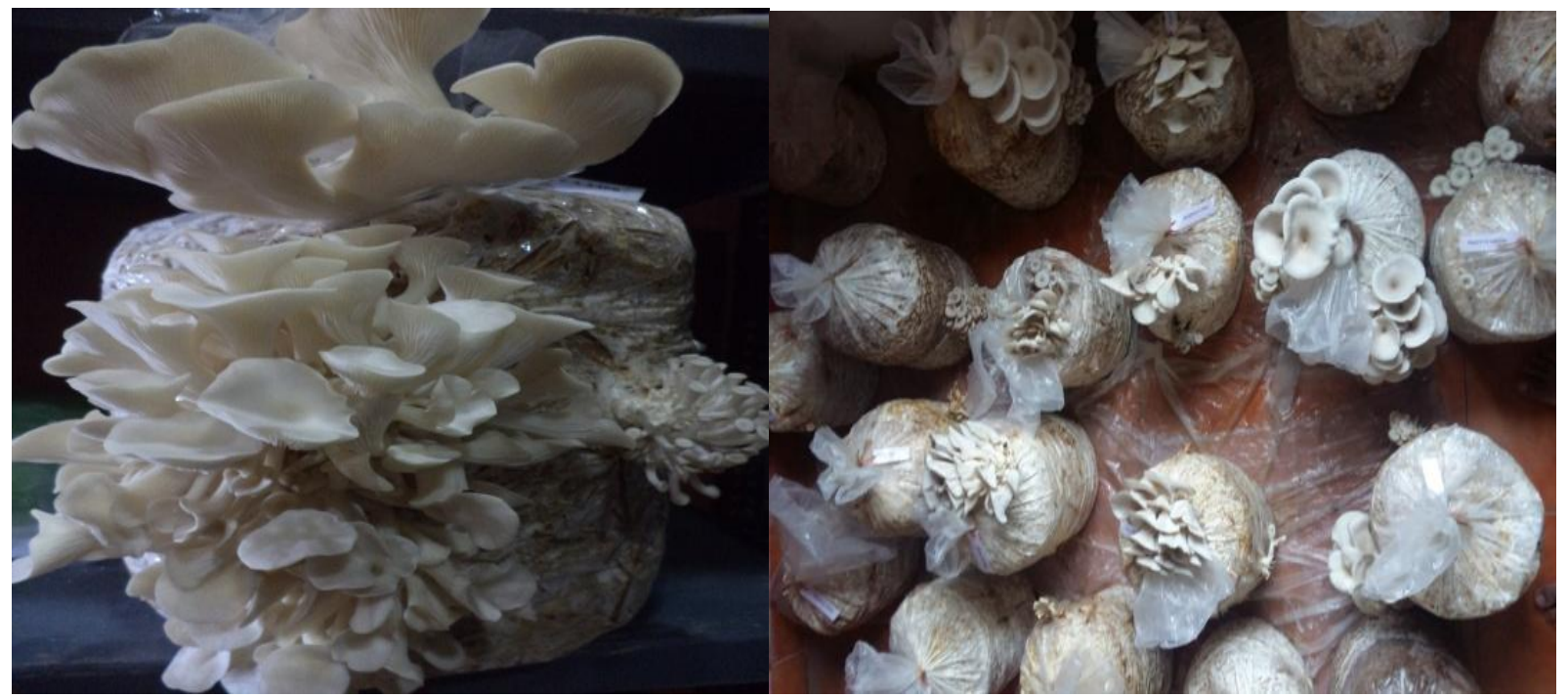

Plate 7 Spawn running of Intraspecific Hybrids, Plate 8: Pin Head formation of Intraspecific Hybrids, Plate 9 \& Plate 10: Fruit body production of Intraspecific Hybrids 
Table.1 PFm: P. flabellatus monosporus culture. PFm $\times$ PFm: different monosporus culture crossed with each another

\begin{tabular}{|c|c|}
\hline Parentage & Hybrids \\
\hline $\mathrm{PF9m} \times \mathrm{PF} 10 \mathrm{~m}$ & $\mathrm{PF} \times \mathrm{PF} 1, \mathrm{PF} \times \mathrm{PF} 2, \mathrm{PF} \times \mathrm{PF} 3$, \\
\hline PF9m $\times$ PF11m & $\mathrm{PF} \times \mathrm{PF} 4, \mathrm{PF} \times \mathrm{PF} 5$ \\
\hline PF9m $\times$ PF1m & PF $\times$ PF6, PF $\times$ PF7, PF $\times$ PF8, \\
\hline $\mathrm{PF} 10 \mathrm{~m} \times \mathrm{PF} 9 \mathrm{~m}$ & PF $\times$ PF9, PF $\times$ PF10, PF×PF11, \\
\hline $\mathrm{PF} 10 \mathrm{~m} \times \mathrm{PF} 11 \mathrm{~m}$ & $\mathrm{PF} \times \mathrm{PF} 12, \mathrm{PF} \times \mathrm{PF} 13, \mathrm{PF} \times \mathrm{PF} 14$, \\
\hline $\mathrm{PF} 10 \mathrm{~m} \times \mathrm{PF} 1 \mathrm{~m}$ & $\mathrm{PF} \times \mathrm{PF} 15, \mathrm{PF} \times \mathrm{PF} 16, \mathrm{PF} \times \mathrm{PF} 17$, \\
\hline $\mathrm{PF} 11 \mathrm{~m} \times \mathrm{PF} 9 \mathrm{~m}$ & $\mathrm{PF} \times \mathrm{PF} 18, \mathrm{PF} \times \mathrm{PF} 19, \mathrm{PF} \times \mathrm{PF} 20$, \\
\hline $\mathrm{PF} 11 \mathrm{~m} \times \mathrm{PF} 10 \mathrm{~m}$ & $\mathrm{PF} \times \mathrm{PF} 21, \mathrm{PF} \times \mathrm{PF} 22, \mathrm{PF} \times \mathrm{PF} 23$, \\
\hline $\mathrm{PF} 11 \mathrm{~m} \times \mathrm{PF} 10 \mathrm{~m}$ & $\mathrm{PF} \times \mathrm{PF} 24, \mathrm{PF} \times \mathrm{PF} 25, \mathrm{PF} \times \mathrm{PF} 26$ \\
\hline PF1m $\times$ PF9m & $\mathrm{PF} \times \mathrm{PF} 27, \mathrm{PF} \times \mathrm{PF} 28, \mathrm{PF} \times \mathrm{PF} 29$, \\
\hline PF1m $\times$ PF10m & $\mathrm{PF} \times \mathrm{PF} 30, \mathrm{PF} \times \mathrm{PF} 31$, \\
\hline $\mathrm{PF} 1 \mathrm{~m} \times \mathrm{PF} 11$ & $\mathrm{PF} \times \mathrm{PF} 32, \mathrm{PF} \times \mathrm{PF} 33, \mathrm{PF} \times \mathrm{PF} 34$, \\
\hline
\end{tabular}

Table.2 ICRN: intraspecific crosses number, SR: Duration (days) between Spawning to spawn running, PH: Duration (days) between Spawn running to pinhead formation of fruit body, $1^{\mathrm{ST}} \mathrm{F}$ : Duration (days) between pinhead formation to first flushes of fruit body, $2^{\mathrm{ND}} \mathrm{F}$ : first flushes to second flushes of fruit body, Fwt: fresh weight (gram) of total mushroom yield till $2^{\text {nd }}$ flushes, Dwt: dry weight (gram) of total mushroom yield till $2^{\text {nd }}$ flush, BE\%: biological efficiency on the basis of dry weight of mushroom. Most\%: moisture content in mushroom

\begin{tabular}{|l|c|c|c|c|c|c|c|c|}
\hline ICRN & SR & PH & $\mathbf{1}^{\text {ST }} \mathbf{F}$ & $\mathbf{2}^{\text {ND }} \mathbf{F}$ & $\mathbf{F w t}$ & Dwt & BE\% & Most\% \\
\hline PF X PF1 & 18 & 4 & 3 & 8 & 962 & 98.57 & 9.86 & 89.75 \\
\hline PF X PF2 & 19 & 4 & 2 & 10 & 921 & 91.25 & 9.13 & 90.09 \\
\hline PF X PF4 & 21 & 6 & 2 & 8 & 891 & 86.94 & 8.69 & 90.24 \\
\hline PF X PF5 & 17 & 4 & 3 & 7 & 940 & 99.68 & 9.97 & 89.40 \\
\hline PF X PF7 & 23 & 3 & 2 & 7 & 931 & 91.41 & 9.14 & 90.18 \\
\hline PF X PF9 & 21 & 5 & 2 & 8 & 985 & 102.46 & 10.25 & 89.60 \\
\hline PF X PF10 & 21 & 6 & 3 & 8 & 1074 & 108.11 & 10.81 & 89.93 \\
\hline PF X PF11 & 24 & 5 & 2 & 7 & 856 & 87.18 & 8.72 & 89.82 \\
\hline PF X PF12 & 21 & 6 & 2 & 10 & 848 & 80.27 & 8.03 & 90.53 \\
\hline PF X PF13 & 21 & 4 & 4 & 9 & 937 & 90.78 & 9.08 & 90.31 \\
\hline PF X PF16 & 23 & 5 & 3 & 8 & 900 & 88.22 & 8.82 & 90.20 \\
\hline PF X PF17 & 21 & 7 & 2 & 10 & 803 & 80.83 & 8.08 & 89.93 \\
\hline PF X PF19 & 0 & 0 & 0 & 0 & 0 & 0.00 & no & 0.00 \\
\hline PF X PF20 & 0 & 0 & 0 & 0 & 0 & 0.00 & no & 0.00 \\
\hline PF X PF22 & 22 & 7 & 3 & 8 & 992 & 93.84 & 9.38 & 90.54 \\
\hline PF X PF24 & 19 & 3 & 4 & 14 & 1150 & 117.44 & 11.74 & 89.79 \\
\hline PF X PF25 & 17 & 7 & 4 & 9 & 666 & 66.80 & 6.68 & 89.97 \\
\hline PF X PF26 & 17 & 4 & 3 & 13 & 871 & 85.46 & 8.55 & 90.19 \\
\hline PF X PF27 & 17 & 0 & 0 & 0 & 0 & 0.00 & no & 0.00 \\
\hline PF X PF33 & 16 & 2 & 3 & 10 & 1079 & 109.58 & 10.96 & 89.84 \\
\hline PF control & 24 & 6 & 2 & 8 & 777 & 75.28 & 7.53 & 90.31 \\
\hline
\end{tabular}


Table.3 Nitrogen $\%$ and protein $\%$ present in dry matter of $P$. flabellatus hybrids

\begin{tabular}{|c|c|c|}
\hline CROSSES & NITROGEN (\%) & PROTEIN (\%) \\
\hline PF X PF1 & 3.64 & 35.50 \\
\hline PF X PF2 & 3.08 & 36.25 \\
\hline PF X PF3 & 0 & 0.00 \\
\hline PF X PF4 & 3.36 & 35.75 \\
\hline PF X PF5 & 3.78 & 33.75 \\
\hline PF X PF7 & 2.8 & 30.50 \\
\hline PF XPF-9 & 2.94 & 29.50 \\
\hline PF X PF10 & 3.08 & 37.00 \\
\hline PF X PF11 & 3.22 & 37.25 \\
\hline PF X PF12 & 2.8 & 26.75 \\
\hline PF X PF13 & 3.64 & 35.25 \\
\hline PF X PF16 & 3.08 & 30.25 \\
\hline PF X PF17 & 2.94 & 32.25 \\
\hline PF X PF19 & 0 & 0.00 \\
\hline PF X PF20 & 0 & 0.00 \\
\hline PF X PF22 & 3.64 & 37.75 \\
\hline PF X PF24 & 3.08 & 34.25 \\
\hline PF X PF25 & 2.94 & 28.13 \\
\hline PF X PF26 & 3.08 & 35.75 \\
\hline PF X PF27 & 0 & 0.00 \\
\hline PF X PF33 & 2.94 & 30.25 \\
\hline PF control & 2.94 & 25.50 \\
\hline
\end{tabular}

Fresh weight, dry weight and moisture \% of intraspecific hybrids

Highest fresh weight and dry weight was found in PF X PF33, PF X PF24, PF X PF10 of about 1150 to 1074 and 117.44 to 108.11 gram per cylinder till $2^{\text {nd }}$ flushes which will match with the result of Saha et al., (2004) who recorded that the average yield of $P$. ostreatus was 210.6 - 646.9 gram per flushes in different substrate. Most of the hybrids were found with good yielding capacity as compare to parent. Similar kind of result was found by Kaur et al., (2007) among monokaryons of Pleurotus florida PAU-5, Out of which PFJ 11 yielded out the parent while average weight of fruit bodies was higher in PFJ 13 (9.9 g) as compared to parent (9.6 g). Spawn run was recorded faster in PFJ 11 (39 days) and PFJ14 (41 days) with respect to that of the parent (48 days). Peng et al., (2001) also obtained some highly productive strains through mating which took 54.4 to 60 days from inoculation to the end of the crop and they reacted differently to the composition of substrate in the aspect of productivity. $\mathrm{BE} \%$ is directly related with the yield of the mushroom, all the above hybrids having high yielding capacity contain greater value of $\mathrm{BE} \%$ of about 11.7 to 10 . $\mathrm{BE} \%$ was found in higher value as comparing with the literature which are varying from 4.08 to 5.03\% (Bhatti et al., 2007; Holtz et al., 2009; Furlan et al., 2008, Oliveira et al.,2007;). Moisture \% did not shows any variation as compare to parents which was around $89 \%$ $90 \%$, which can correlate will almost all researcher who found moisture content of about 85\% - 95\% (Tewari, 1986; Ahmed et al., 2013). 
Nitrogen $\%$ and protein $\%$ present in $P$. flabellatus hybrids

Almost all the hybrid had showed the positive relations between the Nitrogen and protein content. PF $\times$ PF5 showed higher nitrogen (3.78\%) which was closely followed by $\mathrm{PF} \times \mathrm{PF} 1, \mathrm{PF} \times \mathrm{PF} 13, \mathrm{PF} \times \mathrm{PF} 22(3.64 \%)$. All the hybrids except $\mathrm{PF} \times \mathrm{PF} 7$ and $\mathrm{PF} \times \mathrm{PF} 12$ shows the higher nitrogen content as compare to the parent $P$. flabellatus (2.94\%). $\mathrm{PF} \times \mathrm{PF9}$, $\mathrm{PF} \times \mathrm{PF} 17, \mathrm{PF} \times \mathrm{PF} 25$, and $\mathrm{PF} \times \mathrm{PF} 33$ showed same amount of nitrogen with the parent. Protein content was found highest in $\mathrm{PF} \times \mathrm{PF} 22, \quad \mathrm{PF} \times \mathrm{PF} 11, \quad \mathrm{PF} \times \mathrm{PF} 10, \quad \mathrm{PF} \times \mathrm{PF} 2$ $(37.75-36 \mathrm{mg} / \mathrm{g}$ of fresh mushroom). All the hybrids showed the higher content of protein as compare to the parent $(25 \mathrm{mg} / \mathrm{g}$ of fresh mushroom). When two parameters were taken into consideration, $\mathrm{PF} \times \mathrm{PF} 4$ and $\mathrm{PF} \times \mathrm{PF} 22$ have the highest nutritive value which was followed by $\mathrm{PF} \times \mathrm{PF} 1, \mathrm{PF} \times \mathrm{PF} 13, \mathrm{PF} \times \mathrm{PF}$, PF $\times$ PF2, PF $\times$ PF26, $\quad$ PF $\times$ PF10, $P F \times P F 11$, $\mathrm{PF} \times \mathrm{PF} 24$. Pleurotus species are considered to be one of the most efficient producers of food protein (Ogundana and Okogbo, 1981). Manzi et al., (2001) reported that chemical composition of mushroom will varies from species to species, it also depends on different substrate, atmospheric condition, age and part of fructification. Bernas et al., (2006) showed that the total nitrogen content ranged between 3.3-4.0g and proteinaceous nitrogen was 2.0$2.2 \mathrm{~g}$ per $100 \mathrm{~g}$ dry weight of mushroom. Ahmed et al., (2013) evaluated yield and chemical composition of oyster mushroom strains newly introduced in Bangladesh. The strains were $P$. high-king (strain PHK), $P$. ostreatus (strain $\mathrm{PO} 2$ ), and $P$. geesteranus (strains PG1 and PG3). They observed that different strains of same Pleurotus sp differed in $\mathrm{N}, \mathrm{P}, \mathrm{K}, \mathrm{Na}$ and protein content (Table 3). The results are in accordance with Bhattacharya et al., (2015) who suggested that the nitrogen content of $P$. ostreatus are $4.03 \%-4.52 \%$. Considering all the quantitative parameters like biological efficiency, yield of 1st and 2nd harvest, $\mathrm{PF} \times \mathrm{PF} 24, \mathrm{PF} \times \mathrm{PF} 33, \mathrm{PF} \times \mathrm{PF} 10, \mathrm{PF} \times \mathrm{PF} 9$ and $\mathrm{PF} \times \mathrm{PF} 22$ may be selected for higher production.

\section{References}

Ahmad, I., 1986. Some studies on oyster mushroom (Pleurotus spp.) on waste material of corn industry. M.Sc., thesis. Department of plant Pathology, Faisalabad, p: 50 .

Ahmed, M., Abdullah, N., Ahmed, K., U. and Bhuyan, M. H. M., 2013. Yield and nutritional composition of oyster mushroom strains newly introduced in Bangladesh. University of Malaya, Faculty of Science, Agricultural University, Faculty of Agriculture, Department of Biochemistry, Dhaka- 1207.

Ashraf, J., Ali, M.A., Ahmad, W., Ayyub, C.M., Shafir, J., 2013. Effect of Different Substrate Supplements on Oyster Mushroom (Pleurotus spp.) Production. Food Science and Technology 1(3): 44-51, 2013.

Bahukhandi, D. and Sharma, R. K., 2002. Interspecific hybridization between Pleurotus species. Indian Phytopathology 55(1):61-66.

Bano, Z., Srinivasan, K.S. and Srivastava, H.C., (1962).Amino acid composition of the protein from a mushroom (Pleurotus flabellatus). Applied Microbiology 11: 184187.

Bhattacharjya DK, Paul RK, Miah MN, Ahmed KU., 2015. Comparative Study on Nutritional Composition of Oyster Mushroom (Pleurotus ostreatus Fr.) Cultivated on Different Sawdust Substrates J, Bioreasearch Communication; 1(2): 93-98.

Bhatti, M. I., Jiskani, M. M., Wagan, K. H., Pathan, M. A., Magsi, M. R., 2007. Growth development and yield of oyster mushroom Pleurotus ostreatus (JACQ.EX.FR) Kummer as affected by different spawn rates. Pakistan Journal of Botany, 39(7), 2685-2692. 
Furlan, S. A., Gern, R. M. M., Wisbeck, E. Bonatti, M., Silveira, M. L. L., Silva, H. H., (2008). Possibilities of Pleurotus aplications in food health and environmental technologies. In A. Koutinas, A. Pandey \& C. Larroche (Eds.), Current topics on bioprocess in food industry (Vol. 2, cap. 16, pp. 197-203). New Delhi: Asiatech Publishers.

Holtz, M., Borges, G. M., Furlan, S. A., Wisbeck, E., 2009. Cultivo de Pleurotus ostreatus utilizando resíduos de algodão da indústria têxtil. Revista de Ciências Ambientais, 3(1), 37-51.

Jackson, M.L. (1958) "Soil Chemical Analysis" Prentice-Hall Inc.

Jackson, N.L., 1973. Soil chemical analysis Prentice Hall New Delhi.

Jaswal, R., Sodhi, K., Kapoor, S. and Khanna, P. K., 2013. Development of high yielding morphologically improved strains of Pleurotus (Oyster Mushroom) through inter-specific hybridization, Indian Journal of Agricultural Sciences 83(4):374-379.

Jodon, M.H. and Royse, D.J., 1979. Care and handling of cultures of the cultivated mushroom. The Pennsylvania Agricultural Experiment Station Bulletin No. 258. Pennsylvania State University, University Park, $P A$.

Kaur, J. 2007. Selection and breeding for the improvement of oyster mushroom, Pleurotus florida. pp 55-56, M.Sc. Thesis, Punjab Agricultural University, Ludhiana, India.

Lowry, O.H., Rosenbrough, N.J., Farr, A.L., Randall, R.J., 1951, Protein measurement with the folin Penol Reagent, $J$ Biol Chem 193, pp 265-275.

Manzi, P., Agguzzi, A. and Pizzoferrato, L., 2001. Nutritional mushrooms widely consumed in
Italy. Food Chemistry 73: 321-325.

Ogundana, S., K. and Okogbo, O., 1981. The nutritive value of some Nigerian edible mushrooms. International Journal of Mushroom science. XI,. Proceedings of 11th international scientific congress on cultivation of edible fungi, Australia, pp. 123-131.

Oliveira, M. A., Donega, M. A., Peralta, R. M., \& Souza, C. G. M., 2007. Produção de inóculo de cogumelo comestível Pleurotus pulmonarius (Fr.) Quélet - CCB 19 a partir de resíduos da agoindústria. Food Science and Technology, 27(Supl.), 84-87.

Oliveria, P.F.B., Guilherme, J., Pricila, E., Miranda, R.M., Aparecida, S. and Elisabeth., 2014. The production of Pleurotus sajor-caju in peach palm leaves (Bactris gasipaes) and evaluation of its use to enrich wheat flour. Food Science and Technology. ISSN 0101-2061.

Peng, J.T., Dai, M.C., Tsai, Y.F., Chen, M.H., Chen, J.T., 2001, Selection and breeding of king oyster mushroom, J. Agric. Res. China, 50, pp. 43-58.

Quimio, T. H., 1978. Indoor cultivation of Pleurotus ostreatus. Philippines Agriculturist 61: 253-262.

Shah, Z.A., Ashray, M. and Ishtiod, M., 2004. Comparative study on cultivation and yield performance of oyster mushroom (Pleurotus ostreatus) on different substrates. Pak. J. Nut. 3: 158-160.

Tan, K.K., 1981. Cotton waste is a fungus (Pleurotus). good substrate for cultivation of Pleurotus ostreatus the oyster mushroom. Mushroom Science, 11:705710.

Tewari, R.P., 1986. Mushroom cultivation. Extension Bulletin. Indian Institute of Horticulture Research, Bangalore, India, 8: 36.

\section{How to cite this article:}

Deewakar Baral, Ayon Roy, Sukram Thapa and Karma Chewang Bhutia. 2017. Development of Intraspecific Hybridization of Pleurotus flabellatus for Better Yield and Nutrition. Int.J.Curr.Microbiol.App.Sci. 6(11): 735-742. doi: https://doi.org/10.20546/ijcmas.2017.611.086 